\title{
PERAN KEPEMIMPINAN KEPALA MADRASAH DALAM MENGEMBANGKAN BUDAYA MUTU
}

\author{
Oleh: \\ Muhamad Abdul Manan \\ Universitas Ibrahimy Situbondo \\ mananmanis@gmail.com
}

\begin{abstract}
:
The world is undergoing rapid and global changes. Therefore, in the era of globalization, quality of human resources is needed. The thing that needs to be considered in improving the quality of madrasas is building a quality culture of madrasas. The headmaster of the madrasah provides an important role in the formation of a strong madrasa culture.

This study aims to: (1) Obtain a description of the steps of the headmaster of the madrasah in developing the madrasah quality culture, (2) to know the Quality Culture Reality of Madrasah.

This research shows that (a) the head of the madrasah articulates the vision and mission for the effectiveness of his leadership in bringing madrasah to become culturally quality continuously. (b) The head of the madrasah has leadership values that are believed, and then realized into the life of the madrasah organization, and has an impact on efforts to improve the quality culture of madrasah. For the process of developing a quality culture through four phases, they are the preparation phase, the acceptance phase, the implementation phase and the commitment phase.
\end{abstract}

Keyword: Kepemimpinan, Kepala Madrasah, Budaya, Mutu

\section{A. Pendahuluan}

Mutu pendidikan saat ini menjadi salah satu isu penting dalam penyelenggaraan pendidikan. Penjelasan tentang pendidikan harus bermutu juga di tegaskan UU. No. 20 tahun 2003 tentang Sistem Pendidikan Nasional di Indonesia pada pasal 4 ayat 6 yang di dalamnya menyatakan bahwa: sebuah penyelenggaraan Pendidikan dengan memberdayakan melibatkan semua komponen masyarakat melalui peran serta baik penyelenggaraan maupun pada pengendalian mutu layanan pendidikan agar tercapai tujuan pendidikan ${ }^{1}$.

1 UU. No. 20 Tahun 2003 tentang Sistem Pendidikan Nasional (Sisdiknas) (Yogyakarta: Pustaka Widyatama, 2003), 10. 
Kenyataan menunjukkan kemerosotan mutu pendidikan terlihat hampir di setiap jenjang pendidikan baik tingkat dasar hingga tingkat pendidikan tinggi. Indikator kemerosotan yang bisa kita lihat pada mutu pendidikan ditunjukkan antara lain dengan hasil ujian nasional berbasis komputer siswa untuk berbagai bidang studi pada jenjang pendidikan dasar dan menengah yang tidak memperlihatkan kenaikan, bahkan boleh dikatakan konstan dari tahun ke tahun, kecuali pada beberapa madrasah dengan jumlah yang relatif kecil ${ }^{2}$. Hal ini terjadi karena seringkali pengelolaan pendidikan yang dilakukan lebih menitikberatkan pada aspek kuantitas daripada kualitas, di samping itu juga kurangnya perhatian pada upaya untuk meningkatan kualitas proses belajar mengajar serta perbaikan kualitas manajemen madrasah atau manajemen pengelolaan pendidikan.

Upaya Peningkatan Mutu pendidikan atau mutu madrasah disetiap lembaga pendidikan akan membutuhkan usaha yang keras salah satunya meningkatkan mutu lulusan sebgai tolak ukur keberhasilan lembaga. Keberhasilan suesuatu pendidikan merupakan hal mustahil jika pendidikan atau madrasah tidak dapat menghasilkan output atau lulusan yang bermutu, oleh karena itu dibutuhkan proses pendidikan yang bermutu. Pendidikan yang bermutu bersifat menyeluruh, yang mana pendidikan yang mampu memanfaatkan komponen pelaksana serta kegiatan pendidikan yang menunjang pendidikan yang bermutu sebagai manifistasi keseluruhan mutu atau total quality. Salah satu strategi yang digunakan dalam pemakaian manajemen mutu terpadu atau total quality manajemen (TQM) didalam dunia pendidikan adalah semua institusi pendidikan dapat memposisikan dirinya sebagai institusi yang mampu melayani jasa yakni institusi yang mampu menhadirkan pelayanan yang memuaskan keinginkan stakeholder.

Budaya organisasi yang bermutu sangat di butuhkan dalam proses membentuk bentuk perubahan budaya mutu yang mana ini bertujuan untuk membentuk mutu dan menjadikan mutu sebagai orientasi semua komponen didalam tubuh instansi pendidikan yang ada. Jika manajemen mutu ini dibutuhkan pada institusi pendidikan, maka peran pemimpin harus membangun kesadaran anggotanya, mulai dari pemimpin sendiri, tenaga pendidik, tenaga kependidikan, peserta didik, dan berbagai unsur yang terkait, misalnya stakeholder yang di dalamnya ada wali murid dan para pengguna lulusan. Di sini peran pemimpin penting mengembangkan faktor inovasi dan faktor motivasi agar secara bertahap dan pasti budaya

\footnotetext{
${ }^{2}$ Umaedi, Manajemen Peningkatan, 2.
} 
mutu itu akan berkembang di dalam organisasi institusi pendidikan.

Berdasarkan pemikiran di atas, peran peran kepemimpinan kepala madrasah dalam hubungannya dengan budaya dan birokrasi di madrasah sangat penting. Oleh sebab itu, penelitian ini bermaksud untuk meningkatkan pemahaman tentang sosok pemimpin kepala madrasah dalam pengembangan budaya yang bermutu, mencakup nilai, kenyakinan, tindakan baik yang bersifat verbal atau material di madrasah.

Peran kepemimpinan kepala madrasah dalam meningkatkan budaya mutu dalam rangka meningkatkan pendidikan yang bermutu pada institusi yang di pimpim merupakan hal yang harus di lakukan. Peran kepemimpinan kepala madrasah dalam utnuk pengembangan budaya mutu ada beberapa hal yang harus diperhatikan yaitu, (1) konstruksi budaya (cultural building), yang didalamnya ada visi sebagai keinginan panjang, ada misi sebagai tahapan menuju ke visi, ada tujuan sebagai langkat pendek, tak kalah penting harus ada value atau nilai didalamnya termasuk keyakinan, kemudian sistem penghargaan, tak kalah pentingnya yaitu hubungan emosional dan sosial serta desain organisasi, (2) konstruksi pribadi /personal building, berupa uswah pemimpin, meliputi perilaku pribadi yang baik , perilaku kepemimpinan dan eksen administrasi ${ }^{3}$.

Fokus penelitian adalah suatu hal yang prinsip dalam menulis karya ilmiah serta merupakan landasan perubahan yang dominan. Maka penulis riset ini penulis mefokuskan masalah sebagai berikut: 1) tentang bagaimanakah peran kepemimpinan kepala madrasah dalam mengembangkan budaya mutu; dan 2) mengenai bagaimanakah realitas budaya mutu yang terjadi di madrasah.

\section{B. Metode Penelitian}

Metodologi penelitian ini menggunakan jenis penelitian kualitatif disini berusaha mendeskripsikan hasil penelitian. Dalam penelitian ini berusaha mengumpulkan data dengan latar alami (natural setting) sebagai sumber utama dalam penelitian. Sedangkan untuk pendekatannya memakai fenomenologis (phenomenological approach). Pendekatan ini digunakan untuk mengamati fenomena konseptual utama yang diamati melalui kegiatan dan pemikiran guna memahami makna yang disusun oleh subyek di sekitar kejadian sehari-hari. Peneliti disini berusaha memaparkan data alami sesuai aturan penelitian yang ada untuk

${ }^{3}$ Caldwell, B.J. \& Spink, JM., Leading the Self Managing School (London: The Falmer Press, 1992), 143. 
menampilkan data se objektif mungkin.

Prosedur pengumpulan data Untuk memperoleh data secara holistik dan integratif, guna memperoleh data seobjektif mungkin dengan memperhatikan relevasnsi data dan fokus serta tujuan penelitian maka penelitian ini menggunakan teknik wawancara, teknik observasi dan teknik studi dokumentasi. Data yang di peroleh di harapakan sesuai dengan hasil wawancara, observasi dan dokumentasi di tindak lanjuti dengan triangulasi agar supaya kebenaran dari data bisa di kroscek. Maka harapanya adalah menemui kejenuhan dari data yang ini menunjukkan ke valitan data.

Analisa atau Analisis data menjadi proses sistimatis untuk mengkaji dan mengumpulkan data agar supaya data ini menjadi kroscek hasil transkrip wawancara, catatan lapangan dan dokumentasi lapangan.

Miles dan Huberman mengatakan, dalam rangka kegiatan menganalis data langsung menggunakan ketiga teknik secara bersamaan yaitu: reduksi, penyajian dan penarikan kesimpulan sebagai verifikasi data yang telah di lakukan. Secara secara sistematika atau skeptis bisa dilihat pada bagan sebagai berikut:

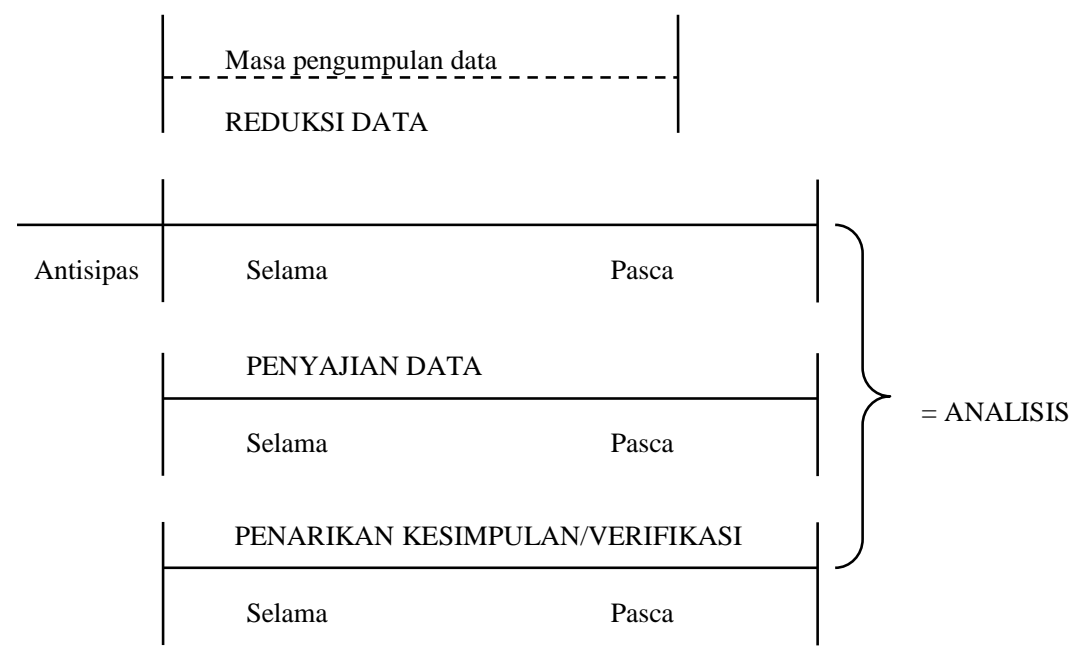

Gambar. Komponen-komponen Analisis Data: Model Alir ${ }^{4}$

\footnotetext{
${ }^{4}$ M.B. Miles dan A.M. Huberman, Qualitative Data Analysis A Sources Book of New Method (Beverly Hill: Sage Publication, 1984), 18.

176 JURNAL LISAN AL-HAL
} 


\section{Kerangka Konseptual}

\section{Konsep Dasar Kepemimpinan}

Konsep dasar kepemimpinan secara umum adalah proses memotivasi, mensitimulus dan mempengaruhi dalam menentukan tujuan organisasi, memotivasi perilaku pengikut untuk mencapai tujuan, mempengaruhi untuk memperbaiki kelompok dan budayanya. Konsep dasar kepemimpinan untuk menginterprestasi mengenai peristiwaperistiwa pengikutnya aktivitas organisasi untuk mendapatkan dukungan dari seluruh organ yang ada di organisasi tersebut.

Secara lebih khusus Yulk, mengatakan kepemimpinan merupakan proses untuk mempengaruhi seseorang atau kelompok untuk mencapai tujuan bersama secara bersama. Beberapa hal untuk memahami definisi Kepemimpinan secara luas adalah sebuah proses yang digunakan seseorang untuk mempengaruhi interpretasi mengenai segala sesuatu peristiwa pada para pengikut, sasaran yang di gunakakan pemimpin untuk melakukan sesuatu dengan memanfaatkan potensi yang ada pada sebuah kelompok atau orang, sedangkan tujuan atau sasaran untuk memelihara hubungan, kerja sama baik antar perorangan atau kelompok, dengan harapan mendapatkan pengaruh dari orang sekitar ${ }^{5}$.

Pengertian kepemimpinan dalam sejumlah kajian memiliki pengertian yang lebih luas yang mana bukan mencakup pada organisasi tertentu akan tetapi pada sosial budaya lebih kuat. Pernyataan ini berdasarkan pencitraan sosiologis terhadap organisasi sehingga dilihat dari sistem sosial yang memiliki dimensi sosial budaya.

Kepemimpinan tidak lagi dipahami secara organik akan tetapi merupakan persatuan untuk membuat organisasi yang lebih kuat dan sehat. Menurut Willer Lane et. al. seperti dikutip Hanson, kepemimpinan disini tidak bisa berdiri sendiri akan tetapi akan selalu berhubungan dengan kebiasaan-kebiasaan yang ada pada sebuah kelompok yang bermanifestasi terhadap organisasi tersebut ${ }^{6}$.

Khusus kepemimpinan di madrasah ada penekanan pada kegiatan yang ada pada madrasah yakni kegiatan belajar mengajar. Disini pemimpin di tutut untuk menguasai di semua lini bukan hanya pada strutural saja akan tetapi di tutut harus memahami sosial budaya yang ada lingkungan madrasah. Kepemimpinan di madrasah harus

${ }^{5}$ Yukl G., Leadership in Organization, Alih Bahasa: Udaya (Jakarta: Prenhallindo, 1998), 1.

${ }^{6}$ Hanson EM., Educational Administration and Organizational Behaviour (Newton, 1991), 184. 
berlangsung dengan interaksi antar individu atau kelompok yang didalamnya terdapat siswa, guru, kepala madrasah, orang tua, masyarakat dan karyawan madrasah. Tujuan terbesarnya dari proses kepemimpinan di madrasah adalah keberlangsungan kegiatan yang efektif dan efisien.

Pembahasan di atas dapat mengidentifikasi beberapa komponen dalam kepemimpinan yaitu: a. keterkaitan anatara pemimpin dan yang dipimpin. b. Pemimpin itu mampu mempengaruhi orang lain untuk melakukan tujuan yang telah di tentukan. c. visi misi menjadi salah satu tujuan bersama yang harus di wujudkan. d. Pemimpin atau kepemimpinan bisa muncul tanpa harus ada organisasi. c. Proses memilih pemimpin bisa melalui tunjukan dari atasan atau dari anggota organisasi tersebut. d. Munculnya kepemimpinan bisa terjadi pada situasi tertentu, baik situasi pengikut maupun lingkungan eksternal.

\section{Peran kepemimpinan kepala madrasah yang Efektif}

Peran kepemimpinan kepala madrasah dalam mewujudkan madrasah yang bermutu ini jelas membutuhkan kepemimpinan madrasah yang efektif yang mana kepala madrasah di tutut untuk memahami semua masalah yang ada termasuk memahami karakter pendidik dan tenaga pendidik yang ada. Kepala madrasah bisa di sebut pemimpin yang efektif jika mampu menciptakan atmosfir kondusif bagi murid-murid untuk belajar, para guru untuk terlibat dan berkembang secara personal dan profesional serta seluruh masyarakat yang termasuk stakeholder, yang harapanya adalah mendapat dukungan yang sangat tinggi terhadap madrasah yang di pimpin.

Kepala madrasah dikatakan pemimpin yang efektif jika mampu mengerakkan semua stakeholder kepada visi misi lembaga yang harapanya adalah membawa kesuksesan madrasah dengan bersama-sama ataua yang di kenal dengan succesfull school.

Peran kepemimpinan kepala madrasah yang efektif selalu dikaitkan tidak bisa lepas dari peran pemimpin sebagai pengelola pembelajaran (instructure manager) menguasai kemampuan kurikulum, pemimpin ide kreatifonal (inspiration leader) mampu menjadi inspirator bagi semua, pengelola sumber daya (manager of resources) peka terhadap SDM, pakar organisasi (organizational expert) fasih terhadap tugas, pemimpin kultural (cultural leader) dan penasehat/pelindung guru (teacher advocate).

Beberapa peran kepemimpinan kepala madrasah yang efektif menurut E. Mulyasa adalah sebagai berikut : 
a. Kepala Madrasah mampu memberdayakan guru-guru untuk melaksanakan proses kegiatan belajar mengajar dengan baik, atau yang sering di sebut PAIKEM.

b. Kepala Madrasah menjalankan tugas dan pekerjaan sesuai dengan waktu yang telah direncanakan.

c. Kepala Madrasah bisa menjalin hubungan yang harmonis dengan masyarakat. Dengan tujuan dapat melibatkan semua masyarakat dalam mengantarkan kesuksesan madrasah.

d. Kepala Madrasah mampu atau berhasil membawa perubahan dalam proses kepemimpinannya yang lebih dewasa yang sesuai dengan kondisi tenaga pendidik dan pendidik.

e. Kepala Madrasah bisa bekerja dengan semua elemen madrasah.

f. Kepala Madrasah Mampu mewujudkan Visi, Misi dan tujuan madrasah secara produktif sesuai dengan apa yang telah di rencanakan? ${ }^{7}$.

Dalam penelitian yang dilakukan Blumberg dan Greenfield, mereka menemukan sejumlah perbedaan peran kepemimpinan kepala madrasah yang efektif dengan kepemimpinan madrasah pada umumnya. Dia mengklasifikasikan kepemimpinan yang efektif berdasarkan delapan macam, yaitu: (1) organisatoris terikat pada ketentuan aturan yang berlaku dalam memecahkan masalah yang berkaitan dengan pengembangan organisasi madrasahnya; (2) pengubah keadaan yang mendasarkan nilai-nilai persuasif (the value based juggler) yaitu mengandalkan nilai-nilai persuasi untuk mempengaruhi orang lain dalam proses perbaikan madrasah dengan tetap berorientasi pada kemajuan belajar murid; (3) penolong sejati yang senantiasa berusaha membantu guru dan staf dalam melaksanakan tugasnya dengam petunjuk baku; (4) perantara yang menerapkan konsep mediator antara madrasahmasyarakat-pemerintah juga di antara guru dalam pertumbuhan di mana semua pihak diuntungkan; (5) humanis menerapkan konsep 'people plus follow throught' "tut wuri handayani" dengan sangat memperhatikan faktor-faktor manusiawi dalam memotivasi dan membangkitkan semangat staf; (6) katalisator yang mempercepat proses penerapan dan perubahan madrasah menjadi efektif diperlukan kekompakan dari semua unsur; (7) rasionalitas yang melakukan perubahan dan perbaikan madrasah dengan perhitungan cermat, hati-hati dan rasional; (8) politikus yang memiiliki kepekaan kebijakan terhadap tuntutan guru, masyarakat dan pemerintah untuk dapat diupayakan membantu pengembangan madrasah dan tidak

7 Mulyasa, E., Manajemen Berbasis Sekolah, Konsep, Strategi dan Implementasi (Bandung: PT Remaja Rosdakarya, 2003), 126. 
menjadi faktor penghambat ${ }^{8}$.

Meskipun keadaan tipe madrasah ini berbeda satu dengan lainnya namun menurut analisa Blumberg dan Greenfield ada tiga faktor menjelaskan keberhasilan mereka yaitu: (1) berkeinginan dan berhasrat kuat membuat madrasah sehebat yang diimajinasikan; (2) bertindak proaktif dan cepat dalam mengambil inisiatif; (3) kreativitas untuk menjadikan diri masuk dalam struktur yang diperankan dan mereka meminta ketepatan waktu dalam peraturan sesuai yang ditetapkan untuk mengejar apa yang mungkin dapat dicapai dalam tujuan personal mereka sebagai kepala madrasah. Ketiga hal tersebut merupakan unsur efektivitas yaitu visi, inisiatif dan kreativitas ${ }^{9}$.

\section{Ciri-ciri Budaya Mutu di Madrasah}

Budaya mutu madrasah perlu di kembangkan mulai sejak dini, kenapa karena terkait dengan budaya berarti mengandung makna kebiasaan, maka oleh karena itu ketika sudah ada niatan mendirikan sebuah lembaga harus dimulai dengan visi misi yang jelas, agar suapaya arah dari madrasah ini sudah difahami oleh semua anggota yang ada dalam madrasah tersebut.

Beberapa makna dari budaya menurut Stoner, dkk., memaknai budaya adalah gabungan dari semua pemikiran dari masyarakat yang kompleks berdasarkan asumsi, tingkah laku masyarakat , cerita masa lalu, mitos-mitos, metafora dan ide-ide yang macam-macam yang menjadi satu untuk menentukan apa arti menjadi anggota masyarakat tertentu ${ }^{10}$. Menurut Krench, budaya adalah pola semua susunan yang menjadi sesuatu, baik internal maupun perilaku yang sudah diadopsi masyarakat sebagai suatu cara tradisional dalam memecahkan masalah-masalah anggotanya ${ }^{11}$. Budaya di dalamnya juga termasuk semua cara yang telah terorganisasi, kepercayaan, asumsi, nilai-nilai budaya implisit, serta premis-premis yang mendasar dan mengandung suatu perintah.

Berbagai aspek budaya, seperti berikut:

${ }^{8}$ Blumberg \& Greenfield W., Stogdels Handbook of Leadership: Survey of Theory and Research (Boston, London, Sidney, Toronto: Allyn \& Bacon Inc., 1980), 123.

${ }^{9}$ Ibid.

${ }^{10}$ Stoner dkk., Manajemen (Jakarta: Prenhallindo, 1995), 49.

${ }^{11}$ Sugeng Listiyo Prabowo, "Penjaminan Mutu dengan Sistem Manajemen Mutu ISO 9001:2000 di Perguruan Tinggi, Studi Multi Situs pada STIE Malangkucecwara Malang dan Universitas Narotama Surabaya", (Disertasi, Universitas Negeri Malang, 2008), 85.

$180 \mid$ JURNAL LISAN AL-HAL 
a) Budaya bagian yang tidak bisa lepas dari konstruksi sosial, beberapa unsur-unsur budaya, seperti nilai-nilai, keyakinan dan pemahaman, yang dianut oleh semua anggota kelompok.

b) Budaya Menuntut pemahaman yang sama bagi masyarak yang ada di dalamnya.

c) Budaya tidak bisa lepas dar kebiasaan atau tradisi yang ada di tempat tersebut.

d) Budaya akan selalu berkembang sepanjang waktu. Baik itu tentang nilai, keyakinan atau kebiasaan yang lainya.

e) Budaya mengarahkan suatu organisasi dan menjamin bahwa para anggotanya berperilaku sesuai dengan norma.

f) Disetiap organisasi budaya itu berbeda-beda ${ }^{12}$.

Budaya termasuk di dalamnya budaya organisasi merupakan kegiatan sehari-hari dari value dan tradisi yang mendasari organisasi tersebut. Semua kegiatan yang dilakukan oleh anggota organisasi baik itu oleh pimpinan atau oleh karyawan dalam sehari-hari itu juga disebut budaya.

Sedangkan untuk budaya mutu itu sendiri adalah suatu sistem value atau nilai dari organisasi yang akan menghasilkan sebuah kondisi yang kondusif untuk agar berlangsungnya sebuah organisasi menuju perbaikan yang bermutu. Dalam budaya mutu terdiri dari nilai-nilai organisasi, tradisi organisasi, prosedur organisasi, dan adanya harapan terhadap produk yang bermutu dari organisasi tersebut ${ }^{13}$.

Woods berpendapat ada enam yang menjadi dasar sebuah organisasi meninginkan budaya yang berkualitas, yaitu meliputi:

1) Kita semua adalah bersama (organisasi, pembekal dan pelanggan);

2) Disini Tiada orang bawah atau atasan yang selalu benar;

3) Adanya keterbukaan dan hubungan yang ikhlas.

4) Adanya target yang telah di tentukan.

5) Kita harus Fokus kepada semua proses yang ada.

6) Tidak ada kata gagal atau kejayaan yang abadi, tetapi pembelajaran daripada pengalaman ${ }^{14}$.

Goetch dan Davis menyebutkan karakteristik umum organisasi

${ }^{12}$ Bounds, G., Beyond Total Quality Management Toward the Emerging Paradigma (New York: McGraw Hill Inc., 1994), 101.

13 Nursya'bani Purnama, Manajemen Kualitas Perspektif Global (Yogyakarta: PT.Ekonisia, 2006), 67.

${ }^{14}$ Kamaruddin Mohd Yusof dkk., Budaya Kualiti dan Amalan Penguruan Institusi Pengajian Tinggi di Malaysia (Malaysia: Pusat Pembangunan Akademik Universiti Kebangsaan Malaysia, 2006), 93-97. 
yang memilki budaya mutu sebagai berikut: a) Tingkah laku pada setiap insan harus mencerminkan slogan organisasi, b) Masukan dari konsumen secara aktif dikumpulkan dan digunakan sebagai dasar perbaikan kualitas secara terus menerus, c) Para pekerja diberikan keterlibatan dan pemberdayaan, d) Pekerjaan dilaksanakan berdasarkan kelompok, e) Adanya tuntutan pada level managemen eksekutif untuk memiliki komitmen dan keterlibatan tanggung jawab terhadap kualitas organisasi yang tidak bisa didelegasikan, f) Sumberdaya yang baik di perlukan untuk menunjang perbaikan yang kontinu, g) Semua kgiatan di perlukan untuk meningkatkan ketrampilan dan keahlian untuk menunjang kualitas, seperti Pendidikan dan pelatihan, h) Kenaikan jabatan atau pemberian hadiah perlu untuk menunjang motivasi karyawan, i) Teman kerja adalah konsumen internal, dan j) Pemasok diperlakukan sebagai partner (mitra kerja) ${ }^{15}$.

Ciri-ciri organisasi yang memiliki budaya mutu yang kuat menurut Juran adalah sebagai berikut:

a) Filosofi dalam organisasi perlu dimanag dijabarkan secara luas tidak sempit.

b) Pentingnya SDM yang punya keahlian berorganisasi.

c) Menyelenggarakan acara-acara untuk kegiatan organisasi

d) Memberi penghargaan bagi karyawan yang berprestasi

e) Komunikasi antar jaringan berjalan efektif

f) Terdapat aturan-aturan yang jelas yang sifanya intern.

g) Terdapat nilai-nilai yang kuat

h) Memiliki standar yang jelas dan tinggi

i) Menjadi kebiasaan bersama sehingga memunculkan Budaya organisasi yang jelas ${ }^{16}$.

Beberapa faktor yang mempengaruhi budaya mutu di madrasah, menurut Burnham yang meliputi: (1) adanya nilai dan misi madrasah, (2) adanya struktur organisasi di madrasah, (3) komunikasi terjalin dengan baik, (4) pengambilan keputusan yang tepat, (5) lingkungan kerja yang kondusif, (6) rekrutmen dan seleksi berdasarkan kebutuhan, (7) perencanaan kurikulum yang jelas, (8) manajemen sumberdaya dan anggaran yang transparan, (9) disiplin waktu dan menaati peraturan, (10) adanya hubungan yang baik dengan masyarakat sekitar ${ }^{17}$.

${ }^{15}$ Nursya'bani Purnama, Manajemen Kualitas, 68.

${ }^{16}$ Ibid.

${ }^{17}$ John West Burnham, Managing Quality in Schools (Effective Strategis for QualityBased School Improvement) (London: Prentice Hall, 1997), 100-101.

182 JURNAL LISAN AL-HAL 


\section{Peran pemimpin dalam Mengembangkan Budaya Mutu}

Peran pemimpin madrasah tehadap budaya mutu dapat dilihat pada penjelasan Owens tentang bagaimana pengaruh kepala madrasah dalam membangun budaya madrasah yang kuat (the strong cultural school). Owens menjelaskannya bahwa kepala madrasah sangat besar peranya terhadap kemajuan madrasah karena kepala madrsah sebagai pucuk pemimpin akan di ikuti semua staf, oleh karena itu dalam mengembangkan budaya mutu di perlukan upaya-upaya untuk menafsirkan Visi, Misi dan tujuan madrasah yang didalamnya mengandung nilai nilai madrasah, keunikan madrasah, sistem pendidikan madrasah, biaya pendidikan madrasah, selain itu diperlukan adanya ikatan organisatoris yang saling percaya dan adanya komitmen antar guru, siswa dan masyarakat ${ }^{18}$.

Dari beberapa pembahasan dan tulisan yang telah ada di atas maka bisa di tarik garis besarnya antara lain:

a. Kepala madrasah sebisa mungkin mampu mengkonstruksi dan menafsirkan visi dan misi madrasah agar terciptanya kesatuan ide (the unity of idea) tentang madrasah yang pada akhirnya mampu di fahami oleh semua anggota organisasi.

b. Menafsirkan dan membumikan nilai-nilai dan keyakinan dalam organisasi madrasah.

c. mendesain struktur organisasi madrasah yang efisen dan efektif serta menempatkan SDM yang berkualitas.

d. Menciptakan simbol dan aksesoris yang dapat memperkuat keunikan madrasah.

e. Memberikan reward yang sesuai terhadap karyawan yang beprestasi dan mampu melakukan pekerjaan dengan baik.

f. Menkstruksi hubungan sosial dan emosional antara siswa, guru, dan masyarakat atas dasar komitmen dan misi organisasi madrasah agar terciptanya kondisi madrasah yang nyaman.

\section{Peran Kepemimpinan Kepala Madrasah dalam Mengembangkan Budaya Mutu}

Pertama, Karakteristik kepemimpinan kepala madrasah dalam mengembangkan Budaya mutu Madrasah. Peran kepemimpinan kepala madrasah dalam mengembangkan budaya mutu di madrasah merupakan strategi baru (new strategy) dalam memimpin madrasah yang memiliki

\footnotetext{
${ }^{18}$ Owens, Organizations Behaviour, 161.
} 
dinamika perubahan yang tinggi dewasa ini. Pendekatan ini menjadi menarik karena budaya sebagai aktor terciptanya madrasah yang berkualitas. Kepemimpinan ini menggunakan budaya dalam mengarahkan organisasi madrasah untuk menciptakan budaya organisasi yang kuat. Hal ini didasarkan pada signifikasi peran pemimpin dalam membentuk dan memperkuat budaya organisasi.

Menurut Sallis, menyebutkan bahwa pemimpinan berperan dalam menciptakan budaya mutu madrasah adalah: 1) Memiliki visi misi dan tujuan yang jelas mengenai mutu terpadu untuk madrasahnya, 2) Pemimpin harus memiliki komitmen yang jelas mengenai perbaikan mutu madrasahnya, 3) Mampu berkomunikasi terhadap stakeholder untuk perbaikan mutu, 4) Menjamin kebutuhan pelanggan sebagai pusat kebijakan dan pekerjaan organisasi, 5) Adanya tempat aduan konsumen, 6) Mempelopori perkembangan staf, 7) Hati-hati dalam menyikapi atau menghadapi kesalahan staf, 8) Menjadi pelopor dan mendorong inovasi organisasi, 9) Memberi kesempatan kepada semua staf untuk bereksprsi dan memberikan pendelegasian yang cocok dan maksimal, 10) Mempunyai sikap teguh dalam menyikapi pelanggaran dalam organisasi, 11) Membudayakan dan membangun budaya kerja efektif, dan 12) Menkstruksi mekanisme yang sesuai dengan aturan yang berlaku dan mengevaluasi keberhasilan ${ }^{19}$.

Kedua, Hubungan Kepemimpinan dan Budaya Organisasi. Adanya hubungan antara kepemimpinan dan budaya organisasi yang berkaitan dengan perilaku pemimpin dengan budaya organisasi dapat dilihat dari bagaimana pemimpin membentuk atau mempertahankan budaya madrasah yang kuat (strength of cultural school) dan punya inegritas yang lebih baik sebagaimana yang dijelaskan oleh Yukl, dan berdasarkan penelitian Trice dan Beyer tentang kepemimpinan pada budaya organisasi sebagai berikut: Banyak hal yang diperhatikan oleh pemimpin untuk membuat lembaga menjadi bermutu. Jauh lebih mudah untuk menanamkan budaya dalam organisasi yang baru daripada merubah budaya organisasi yang sudah dewasa. Namun demikian, kepemimpinan kultural juga penting untuk memperkuat budaya dalam sebuah organisasi yang ada saat ini makmur atau berhasil.

Karena budaya dipengaruhi oleh berbagai perilaku seorang pemimpin, termasuk contoh-contoh yang diterapkan oleh seorang pemimpin, apa yang diperhatikan pemimpin, cara pemimpin tersebut bereaksi terhadap kritik, cara pemimpin tersebut mengalokasikan

\footnotetext{
${ }^{19}$ Edward Sallis, Manajemen Mutu..., 173-174.
} 
imbalan-imbalan, dan cara pemimpin tersebut membuat pilihan, promosi, dan keputusan-keputusan memberhentikan orang. Mekanismemekanisme tambahan untuk membentuk budaya termasuk rancangan struktur organisasi, sistem manajemen, fasilitas, pernyataan formal tentang ideologi dan kisah-kisah formal, dongeng-dongeng serta legendaleganda ${ }^{20}$.

Berdasarkan kutipan di atas dapat dipahami bahwa seseorang pemimpin dituntut untuk mengelola unsur-unsur budaya organisasi sebagai sebuah manifestasi dalam bentuk keyakinan, nilai dan semua perilaku anggota. budaya organisasi dipengaruhi oleh sejauh mana kepemimpinan dapat mengarahkan aktivitas organisasi, baik yang tampak (Tangable) atau tidak tampak (Intangable) untuk membangun budaya organisasi yang kuat, Sebuah hubungan budaya dan kepemimpinan dapat digambarkan sebagai berikut:

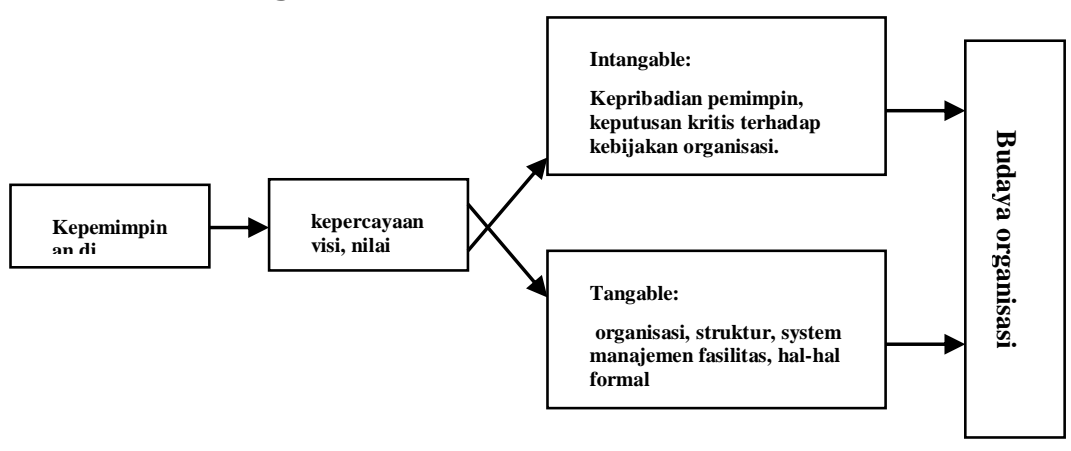

\section{Gambar. kerangka kepemimpinan dalam membudayakan Organisasi ${ }^{21}$}

Budaya organisasi bisa terbentuk dari cita-cita awal ketika mau mendirikannya, karena organisasi adalah satu kesatuan antara visi misi dan tujuan. Sebagaimana Kotter dan Heskett menggambarkan terbentuknya budaya organisasi berawal dari manajemen puncak yang mentransformasi visi, nilai, dan keyakinan organisasi kepada stafnya sehingga menjadi sebuah perilaku, yang kemudian menjadi berkesinambungan dari tahun ke tahun serta terbentuklah budaya organisasi yang kuat ini semua bisa di sebut proses membentuk budaya organisasi. Gambaran dari pembentukan organisasi menurut Kotter dan Hesket sebagai berikut ini:

${ }^{20}$ Yukl, Leadership in, 318.

21 Ibid. 


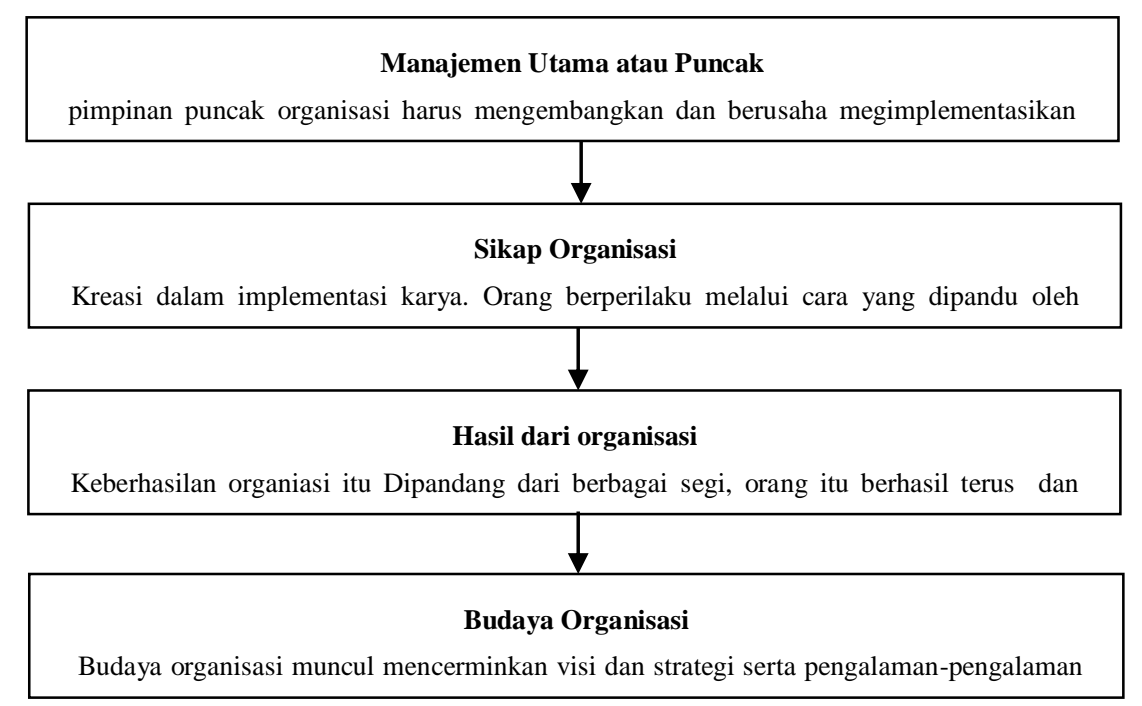

\section{Gambar. Terbentuknya Proses Budaya Organisasi (Kotter dan Heskett) ${ }^{22}$}

Kutipan di atas dapat dipahami bahwa proses terbentuknya budaya organisasi berawal dari kepimpinan puncak yang mampu mengimplementasikan filosofi, visi dan strategi organisasi sebagai dasar perjalanan organisasi, yang kemudian mampu termanifestasi pada perilaku organisasi. Peran kepemimpinan dalam menciptakan budaya organisasi yang kuat merupakan rangkaian proses dari keseluruhan sistem organisasi. Budaya organisasi mencerminkan visi dan strategi serta bagaimana mengimplentasikannya dalam sistem organisasi yang dinamis. Perilaku organisasi akan membentuk suatu budaya yang berkesinambungan dari tahun ke tahun yang memberikan hasil nyata bagi pencapaian tujuan organisasi.

Pemimpin disuatu organisasi, seperti kepala madrasah, baik pemimpin puncak atau pemimpin ditingkat menengah, berperan utama untuk membangun moral kerja dan produktivitas para guru, siswa dan

22 Kotter \& Heskett JL., Dampak Budaya Perusahaan terhadap Kinerja (Jakarta, Prenhallindo, 1997), 9. 
karyawan di madrasah. Pemimpin sangat dibutuhkan untuk membawa kemajuan madrasahnya sebagai visi misi yang sudah disepakati.

Kepala madrasah ditutut untuk memhami semua keinginan dari stakholder agar suapaya dapat memberikan pemahaman yang kuat kepada semua anggota organisasi tentang visi dan misi madrasah sehingga hal tersebut dapat dimanifestasikan dalam bentuk nilai, yang akan menimbulakan keyakinan dan perilaku organisasi sehari-hari.

Kesimpulan sementara dari penjelasan di atas terhadap pembahasan kepemimpinan pada organisasi untuk membuat budaya organisasi harus mempunyai orientasi untuk membangun budaya yang kuat dan mempertahankan secara terus menerus terhadap apa yang telah dicapai organisasi. Harapanya akan memunculkan pemimpin yang efektif dalam membangun inovasi dan mempertahankan budaya organisasi hendaknya memperhatikan strategi kepemimpinan yang akan membawa kemajuan bersama.

Sedangkan terkait dengan pembahasan kepemimpinan pada peran kepala madrasah, tidak jauh beda dengan pembahsan pemimpin pada umumnya yaitu pemimpin harus dapat menciptakan iklim madrasah yang baik dengan dituntut membangaun budaya organisasi yang kuat. Di mana budaya organisasi yang kuat dapat dilihat dari kuatnya visi dan misi madrasah, keyakinan dan nilai yang baik, sistem simbol, sistem penghargaan, hubungan sosial dan emosional yang konstruktif antara kepala madrasah, siswa, guru, karyawan, orang tua, dan masyarakat sekitarnya.

\section{Pembahasan}

Peran kepemimpinan kepala madrasah pada madrasah merupakan bagian dari tugas pokok yang harus dilakukan setiap pemimpin untuk membawa perubahan kepada yang lebih baik. Budaya mutu suatu hal yang wajib dilakukan kalau menginginkan lembaga yang dipimpinnya menjadi bermutu.

Pengembangan budaya mutu di Madrasah merupakan upaya yang dilakukan oleh kepala madrasah untuk meningkatkan dan mempertahankan budaya mutu madrasah. Masing-masing madrasah tersebut memiliki tradisi kuat untuk meningkatkan mutu pendidikan. Kepemimpinan madrasah dapat dilihat dari kuatnya membumikan visi, misi, nilai-nilai kepemimpinannya dan seterusnya. Ini artinya budaya mutu madrasah terwujud dengan perencanaan yang sistematis, sistemik dan terorganisir secara profesional.

Pada pembahasan dari beberapa sumber yang telah di utarakan di

$$
\begin{array}{l|l}
\text { JURNAL LISAN AL-HAL } & 187
\end{array}
$$


atas maupun berdasarkan penelitian di madrasah, maka peran kepemimpinan kepala madrasah dalam mengembangkan budaya mutu berdasarkan temuan di lapangan. sebagai berikut:

\section{Membumikan Visi dan Misi Madrasah}

Membumikan Visi dan misi madrasah merupakan dua inti pokok pada sebuah organisasi yang saling menguatkan antara satu dengan yang lainya. Visi merupakan apa yang dinginkan atau yang dicita-citakan organisasi di masa depan atau bahkan menjadi mimpi atau lamunan (what do we want to have). Sedangkan untuk pengertian misi adalah bentuk langkah pasti untuk mencapai visi atau dalam pengertian lain bagian dari semua komponen organisasi akan menjadi apa di masa depan (what do we want to be) ${ }^{23}$.

Membumikan visi dan misi madrasah merupakan langkah kepala madrasah terhadap menjalankan visi dan misi madrasah untuk memberi makna yang penting bagi peningkatan keefektifan kepemimpinan untuk menciptakan madrasah yang berbudaya mutu secara berkesinambungan dari tahun ke tahun. Disini kepala madrasah mempunyai tugas utama untuk merealisasikan apa yang telah menjadi visi lembaga.

Setiap organisasi pasti mempunyai visi dan misi Visi dan misi merupakan merupakan penggerak dan sumber ide kreatif madrasah untuk melakukan program dan kegiatan yang dapat membina siswa-siswi yang didambakan. Visi dan misi merupakan ikatan moral bagi semua organisasi sehingga kepala madrasah dapat melakukan program kerja madrasah secara berencana dan terorganisasi dengan efektif dan efisien. Untuk itulah kepala madrasah membumikan visi dan misi madrasah dalam bentuk program madrasah setiap tahun. Untuk misi disini bisa ditempuh setiap tahunya untuk menuju visi.

Agar supaya lebih jelas dari pola keterkaitan peran kepemimpinan kepala madrasah dengan membumikan visi dan misi madrasah sebagai berikut:

${ }^{23}$ Madyo Ekosusilo, Sekolah Unggul Berbasis Nilai (Surakarta: Univet Bantara Press, 2003), 43.

188

JURNAL LISAN AL-HAL 


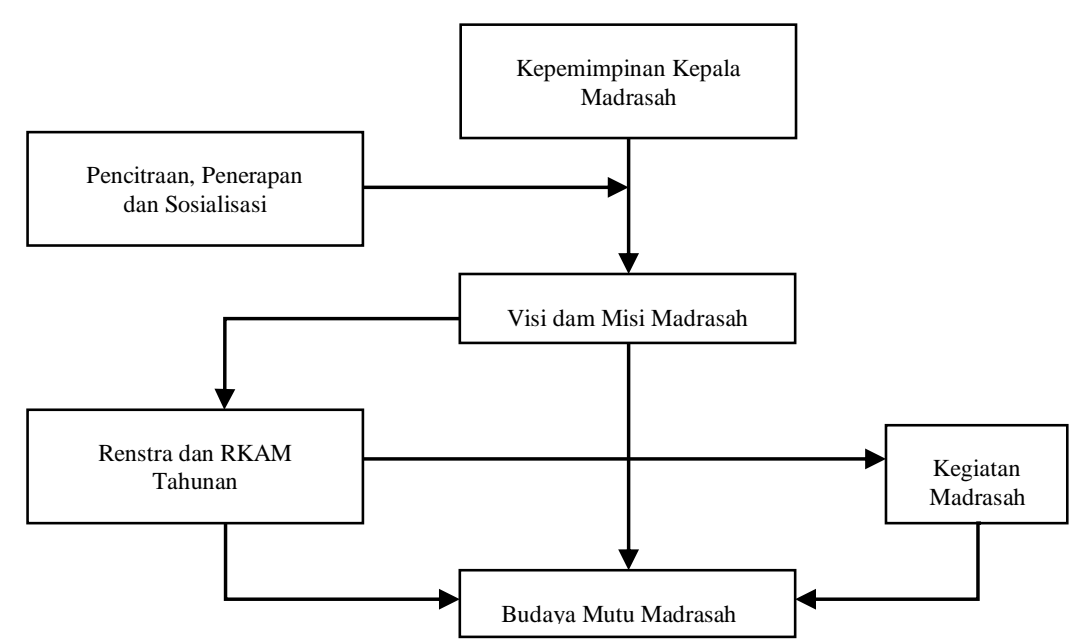

\section{Gambar. Pola Keterkaitan Peran kepemimpinan kepala madrasah dengan membumikan visi dan misi Madrasah}

Peran kepemimpinan kepala madrasah berkaitan dengan upayanya membumikan visi dan misi yang akan berdampak terhadap peningkatan budaya mutu madrasah. Membumikan visi dan misi ditemukan dalam bentuk pencitraan, penerapan dan sosialisasinya pada kehidupan madrasah. Visi dan misi tampak dalam rencana jangka panjang dan rencana tahunan yang terimplikasi pada kegiatan kegiatan madrasah. Dimadrasah untuk sebuah rencana juga disandingkan dengan anggaran pendapatan madrasah yang biasanya dikenal dengan RKAM.

Visi dan misi merupakan salah satu bentuk cerminan dari upaya meningkatkan mutu madrasah. Visi dan misi madrasah berkaitan dengan sejauhmana kepala madrasah mampu meningkatkan pencitraan, penerapan dan sosialisasi pada kehidupan madrasah secara berkesinambungan, sehingga visi dan misi madrasah tersebut dapat mengantarkan terciptanya budaya mutu yang sehat di madrasah.

Merujuk pada tulisan-tulisan di atas dan penelitian di madrasah maka penelitian jurnal ini menerima pendapat Siagian, yang mengatakan visi dan misi merupakan maksud dan kegiatan utama yang membuat organisasi memiliki jati diri yang khas sekaligus yang membedakannya dengan organisasi lain. Demikian juga Morgan, menegaskan tiga fungsi visi madrasah, yaitu: (1) menjadi penyemangat dan ide bagi anggota organisasi di lembaga, (2) Sebagai dasar pembuatan keputusan organisasi, dan (3) Menggerakkan energi anggota agar terfokus pada perbaikan 
mutu $^{24}$.

Visi dan misi diorganisasi merupakan suatu penggerak dan sumber ide kreatif di madrasah untuk melakukan program dan kegiatan yang dapat membina siswa-siswi yang didambakan. Visi dan misi sebagai ikatan moral bagi angggota organisasi sehingga kepala madrasah dapat melakukan program kerja madrasah secara berencana dan terorganisasi dengan efektif dan efisien. Oleh sebab itu kepala madrasah mengmembumikan visi dan misi madrasah dalam bentuk program kerja madrasah setiap tahun.

\section{Membumikan Nilai-nilai Peran kepemimpinan kepala madrasah}

Nilai peran pemimpin merupakan bentuk peran dari keseriusan kepala madrasah untuk membangun budaya mutu dan mebubudayakan organisasi pada madrasah. Kepala madrasah pada masing-masing kasus ini menyakini nilai-nilai yang dapat menciptakan keefektifan kepemimpinannya didalam membangun budaya madrasah.

Nilai-nilai kepemimpinan menjadi keyakinan kepala madrasah yang menjadi dasar untuk mentransfer pada kehidupan warga madrasah. Dengan nilai-nilai ini, maka kepala madrasah berupaya meningkatkan budaya mutu madrasah. Hal ini terkait dengan upaya kepala madrasah untuk meningkatkan keefektifan kepemimpinannya. Nilai-nilai ini mempengaruhi lahirnya budaya madrasah, termasuk mutu madrasah.

Kekuatan nilai menjadi penyemangat semua anggota agar bekerja efektif dan efisien . kepala madrasah di tutut menerapakan nilai-nilai budaya organisasi yang mengacu pada visi misi lembaga. kepala madrasah meningkatkan keefektifan kepemimpinan dengan menerapkan nilai-nilai yang dihargai di madrasah. Nilai-nilai ini mempengaruhi lahirnya budaya madrasah yang bermutu, termasuk mutu madrasah tersebut.

Nilai-nilai kepemimpinan gambar berikut dapat dilihat tentang nilai-nilai kepemimpinan dalam peran kepemimpinan kepala madrasah:

24 Murgatroyd,S \& Collin, Morgan, Total Quality Management and The School (Philadelphia: Open University Press, 1994), 193.

$190 \mid$ JURNAL LISAN AL-HAL 


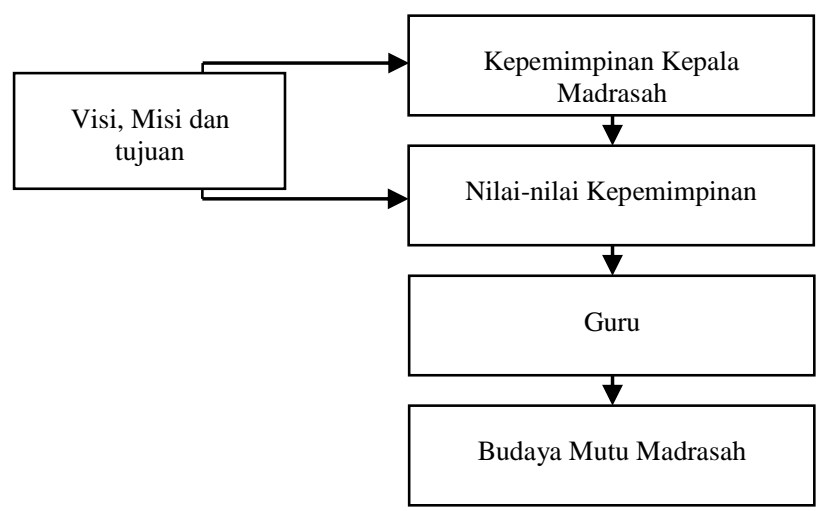

\section{Gambar. Nilai-nilai Kepemimpinan dalam Peran kepemimpinan kepala madrasah}

Nilai dalam kepemimpinan merupakan salah satu faktor yang menjadi pendukung terciptanya budaya mutu yang ada di madrasah. Nilai yang ada diyakini kepala madrasah berkembang menjadi nilai-nilai yang dihargai oleh seluruh komponen madrasah. Kepala madrasah sebagai panutan di madrasah berupaya untuk memimpin berdasarkan nilai-nilai yang dihargai oleh seluruh komponen madrasah. Nilai-nilai kepemimpinan merupakan cerminan visi dan misi madrasah, yang kemudian berpegaruh terhadap kinerja guru guru dan karyawan dan siswa-siswi dalam rangka menciptakan budaya mutu secara kesinambungan. Nilai-nilai itu kemudian terinternalisasi dalam kehidupan sehari-hari di madrasah yang kemudian menjadi budaya madrasah. Untuk itulah nilai-nilai di madrasah merupakan faktor pembentuk dari budaya mutu madrasah.

Berdasarkan temuan tersebut, bahwa penelitian ini menerima pendapat Spink dan Caldwell, bahwa nilai dan keyakinan dalam organisasi madrasah memberi pengaruh terhadap terciptanya madrasah unggul, seperti ditemukan yaitu kualitas, keefektifan, persamaan, efisiensi, dan pemberdayaan ${ }^{25}$. Demikian juga Eko Susilo berpendapat bahwa keunggulan madrasah tercapai akibat nilai dasar yang menjadi keyakinan kepala madrasah, yaitu nilai keunggulan, nilai pengabdian, pelayanan, nilai ibadah dan nilai amanah (tanggungjawab) ${ }^{26}$.

${ }^{25}$ Caldwell B.J. \& Spink, J.M., Leading the Self, 193.

${ }^{26}$ Madyo Ekosusilo, Sekolah Unggul. 


\section{Simbol Madrasah}

Simbol organisasi di setiap organisasi di sesuaikan dengan visi misi madrasah dengan nilai-nilai yang diharapakan atau dihargai di madrasah. Simbol dilembaga merupakan sarana untuk melestarikan dan mengkomunikasikan nilai-nilai kepada warga organisasi dari generasi ke generasi. Sehingga simbol merupakan dimensi keunikan budaya yang dimiliki suatu organisasi, yang membedakannya dengan organisasi lainnya. Simbol ini mencerminkan kerangka ideal dari pencitraan dalam bentuk tindakan dan obyek material organisasi yang diterima oleh warga madrasah.

Simbol madrasah merupakan unsur budaya madrasah yang dimanfaatkan pimpinan untuk melestarikan nilai-nilai yang dihargai di madrasah. Simbol dapat merupakan nilai-nilai yang dihargai oleh seluruh komponen madrasah. Di samping itu, simbol juga mencerminkan keunikan masing-masing madrasah. Makna simbol dan keunikan madrasah merupakan aspek utama peran kepemimpinan kepala madrasah untuk menciptakan madrasah berbudaya mutu secara berkesinambungan. Artinya peran kepemimpinan kepala madrasah dalam mengembangkan budaya mutu dapat dipengaruhi oleh faktor pemaknaan terhadap simbol dalam kehidupan madrasah.

Berdasarkan paparan tersebut di atas, maka penelitian ini menerima pendapat Schein, yaitu simbol-simbol integral merupakan ideide, perasaan, dan tanggapan yang termanifestasi pada suatu artifak organisasi, seperti lambang, lagu, benda, bangunan dan lain-lain. ${ }^{27}$ Kekuatan simbol pada pemaknaan terhadap artifak tertentu tentang nilainilai yang dihargai pada organisasi madrasah. Hal ini juga diungkap Brooks, bahwa simbol organisasi untuk memahami apa yang diharuskan dan diharapkan, apa norma dan nilai-nilai organisasi serta bagaimana diharapkan dan konsekwensinya ${ }^{28}$. Bahkan simbol-simbol dan pemaknaannya dapat merupakan "The heart of the concept of culture". Demikian juga Owens, mengatakan sistem simbol sebagai keunikan madrasah yang diupayakan menjadi kenyataan ${ }^{29}$.

${ }^{27}$ Schein, H.E., Organizational Culture and Leadership (San Francisco: Jersey-Bass Publishers, 1992), 10.

${ }^{28}$ Brooks, I, Organization Behavior: Individual, Group and Organization (London: Prentice Hall, 2003), 249.

${ }^{29}$ Owens, G. Robert, Organizational Behavior Education (London: Allyn \& Bacon, 1990), 16.

192 JURNAL LISAN AL-HAL 


\section{Prosedur Membumikan Visi, Misi dan Nilai-Nilai Peran Kepemimpinan Kepala Madrasah dalam Mengembangkan Budaya Mutu Madrasah}

Pengembangan budaya mutu, merupakan proses perubahan budaya mutu menuju ke arah lebih baik. Proses perubahan menggambarkan mekanisme transisi manusia. Cara kita menghubungkan perubahan dalam kehidupan berkaitan dengan kenyataan bahwa sebagian dari kita sukses dan sebagian lain gagal melanjutkan perubahan. Mereka yang melihat perubahan sebagai sesuatu yang terjadi atau tidak terjadi terlihat terutama mudah terserang guncangan masa depan. Sebaliknya, mereka yang mempunyai sedikit masalah selama perubahan tampak dilindungi oleh kenyataan bahwa mereka mendekati sebagai proses yang sedang berjalan.

Membumikan visi, misi, dan nilai-nilai peran kepemimpinan kepala madrasah dalam mengembangkan budaya mutu melalui tiga fase, yaitu: (1) Preparation (persiapan), (2) Acceptance, (penerimaan), (3) Commitmen (janji) ${ }^{30}$.

Fase persiapan melakukan contact (kontak) dan awareness (kepedulian). Usaha melakukan kontak dalam bentuk rapat, pidato atau memo tidak selalu menghasilkan awareness atau kepedulian, mungkin justru unawareness atau ketidakpedulian. Unawareness akan mengurangi kesempatan mendapatkan cukup persiapan komitmen. Sebaliknya, awareness memajukan proses persiapan. Hasil yang mungkin diperoleh dari awareness adalah confusion (kebingungan) dan understanding (pemahaman). Confusion atau kebingungan mengurangi kemungkinan persiapan yang cukup, sedangkan understanding atau pemahaman memajukan proses yang kedua, yaitu acceptance.

Berdasarkan paparan di atas, maka temuan penelitian ini mendukung pendapat Daft, bahwa proses membumikan visi, misi, dan nilai-nilai budaya mutu melalui tiga tahap, yaitu: (1) tahap persiapan, (2) tahap penerimaan, dan (3) tahap komitmen ${ }^{31}$. Pada tahap persiapan dilakukan dua hal, yaitu memperkenalkan (sentuhan pertama), lewat pidato kepala madrasah guna menyampaikan visi, misi, tujuan dan pengembangan nilai-nilai budaya mutu madrasah. Kedua dibangun proses kesadaran melalui dialog. Tahap penerimaan, pimpinan madrasah

\footnotetext{
${ }^{30}$ Conner, Daryl, R., Managing at the Speed of Change (New York: Villard Books, Random House, Inc.,1992), 149.

31 Richard Daft, Organization Theory and Design.8 ${ }^{\text {th }}$ Edition (Ohio: Thompson, 2004), 425
} 
membantu guru dan karyawan dan komponen madrasah lainnya memahami apa yang terjadi kemudian dan apa saja manfaat bagi madrasah dan mereka semua kalau dilakukan pengembangan nilai-nilai budaya mutu madrasah. Setelah mereka semua mulai bisa menerima, barulah keputusan untuk melakukan implementasi dimulai. Kemudian memasuki tahap komitmen.

\section{E. Simpulan}

Dalam kajian ini disimpulkan beberapa point berikut: Pertama, bahwa peran kepemimpinan kepala madrasah dalam mengembangkan budaya mutu madrasah telah membumikan Visi dan Misi Madrasah yaitu: 1) Kepala madrasah menjadikan visi dan misi madrasah sebagai bentuk pencitraan diri dan pencitraan organisasi madrasah, 2) Kepala madrasah melakukan sosialisasi visi dan misi kepada seluruh warga madrasah, yaitu guru, karyawan, siswa, komite madrasah, dan wali siswa-siswi, 3) Kepala madrasah membumikan visi dan misi berdampak terhadap peningkatan budaya mutu madrasah dan memberikan makna bagi peningkatan keefektifan kepemimpinannya membawa madrasah menjadi madrasah yang berbudaya mutu secara berkesinambungan.

Dirumuskan juga nilai-nilai peran kepemimpinan kepala madrasah meliputi: 1) Nilai-nilai peran kepemimpinan kepala madrasah, yaitu dedikasi yang tinggi, usaha yang maksimal, ikhlas beramal, tawakkal, tabah, tertib dan disiplin, kebersamaan, tanggungjawab, unggul dan inovatif; 2) Nilai-nilai peran kepemimpinan kepala madrasah, yaitu ikhlas beramal, tertib dan disiplin, tanggungjawab, kebersamaan, jujur dan transparan, unggul dan inovatif, 3) Nilai-nilai peran kepemimpinan kepala madrasah, yaitu ibadah, amanah, ikhlas, jujur, kebersamaan, disiplin dan tawadhdhu', 4) Nilai-nilai peran kepemimpinan kepala madrasah berdampak pada upaya peningkatan budaya mutu madrasah.

Kedua, realitas budaya mutu madrasah. Realitas budaya mutu Madrasah adalah baik. Indikatornya adalah: (a) nilai-nilai budaya lembaga telah dimplementasikan dengan baik oleh warga madrasah, (2) komitmen warga madrasah terhadap pelayanan prima adalah baik, (3) Peran kepemimpinan kepala madrasah adalah baik dan ketaatan warga madrasah terhadap sistem adalah baik. 


\section{DAFTAR PUSTAKA}

Bounds, G., Beyond Total Quality Management Toward the Emerging Paradigma, New York: McGraw Hill Inc., 1994.

Brooks, I, Organization Behavior: Individual, Group and Organization, London: Prentice Hall, 2003.

Burnham, John West, Managing Quality in Schools (Effective Strategis for Quality-Based School Improvement), London: Prentice Hall, 1997.

Danin, Sudarwan, Visi Baru Manajemen Sekolah, Jakarta: PT. Bumi Aksara, 2006.

Ekosusilo, Madyo, Sekolah Unggul Berbasis Nilai, Surakarta: Univet Bantara Press, 2003.

Guther, JW., \& RJ., Reed, Administration and Policy : Effective Leadership for American Education, Boston: Allyn Bacon, 1991.

Hamalik, Omar, Sistem Pengelolaan Kelas : Manajemen Pendidikan dalam Regular Program Inservice Education, Jakarta: Rineka Cipta, 1980.

Hanson, EM., Educational Administration and Organitational Behaviour, Newton: 1991.

Hoy, K.W., \& Miskell, CG., Educational Administration Theory Research and Practice, New York: Random House, 1987.

Kasali, Rhenald, Change, Jakarta: PT. Gramedia, 2005.

Kotter \& Heskett JL., Dampak Budaya Perusahaan terhadap Kinerja, Terjemahan: Benyamin Molan, Jakarta: Prenhallindo, 1997.

Miles M.B. dan Huberman A.M., Qualitative Data Analysis A Sources Book of New Method, Beverly Hill: Sage Publication, 1984.

Moleong, Lexy J., Metodologi Penelitian Kualitatif, Bandung: PT. Remaja Rosdakarya, 2002.

Mulyasa E., Manajemen Berbasis Sekolah, Konsep, Strategi dan Implementasi, Bandung: PT. Remaja Rosdakarya, 2003.

Murgatroyd,S \& Collin, Morgan, Total Quality Management and The School, Philadelphia: Open University Press, 1994.

Prabowo, Sugeng Listiyo, Penjaminan Mutu dengan Sistem Manajemen Mutu ISO 9001:2000 di Perguruan Tinggi, Studi Multi Situs pada STIE Malangkucecwara Malang dan Universitas Narotama Surabaya, Disertasi Program Pascasarjana Program Studi Manajemen Pendidikan, Malang: tp., 2008.

Purnama, Nursya'bani, Manajemen Kualitas Perspektif Global, Yogyakarta, PT.Ekonisia, 2006.

Rahim, Husni, Madrasah Terpadu, Jakarta, 2000.

Schein, H.E., Organizational Culture and Leadership, San Francisco: JerseyBass Publishers, 1992. 
Sergiovanni, Thomas J. et. al., Educational Government of Administration, New Jersey: Prentice Hall Inc., 1991.

Sukmadinata, Nana Syaodih, Pengendalian Mutu Pendidikan Sekolah Menengah, PT. Refika Aditama, Bandung, 2006.

Umaedi, Manajemen Peningkatan Mutu Berbasis Sekolah, Jakarta: Direktorat Jenderal Pendidikan Dasar dan Menengah Umum, 1999.

Undang-undang Republik Indonesia Nomor 14 Tahun 2005 tentang Guru dan Dosen serta Undang-undang Republik Indonesia Nomor 20 Tahun 2003 tentang Sisdiknas, Bandung: Penerbit Citra Umbara, 2006.

Uwes, Sanusi, Manajemen Pengembangan Mutu Dosen, Jakarta: Logos Wacana Ilmu, 1999.

Yukl, G., Leadership in Organization, Alih Bahasa: Udaya, Jakarta: Prenhallindo, 1998. 